\title{
28 Research Square \\ Production of Virus Free Sweet Potato (Ipomoea batatas (L.) Lam.) through Meristem Culture and Chemotherapy
}

Neja Jemal

Addis Ababa University

Tileye Feyissa ( $\nabla$ tileye.feyissa@aau.edu.et )

Addis Ababa University College of Natural Sciences https://orcid.org/0000-0001-5103-2924

\section{Research}

Keywords: culture initiation, growth regulators, ribavirin, shoot multiplication, virus indexing

Posted Date: June 17th, 2020

DOI: https://doi.org/10.21203/rs.3.rs-35805/v1

License: (c) (1) This work is licensed under a Creative Commons Attribution 4.0 International License.

Read Full License 


\section{Abstract}

Background: Sweet potato (Ipomoea batatas) ranks the seventh most important crop in the world. As it is propagated vegetatively, viruses accumulate from generation to generation and seriously affect its yield and quality. Currently virus diseases especially double infections are the major constraints of sweetpotato production. Meristem culture, chemotherapy and thermotherapy methods are suggested as the methods of choice to produce virus free planting materials although the success varies among different reports. The objective of this study was to produce virus free sweet potato planting materials through meristem culture and chemotherapy. The micropropagated plants were tested for the viruses.

Results: All of the stock plants of the four varieties of sweet potato tested for 10 different viruses using Nitrocellulose Membranes Enzyme-Linked Immunosorbent Assay (NCM-ELISA) were found to be infected with Sweet potato feathery mottle virus (SPFMV). In addition, Sweet potato chlorotic stunt virus (SPCSV) was detected in 'Ogensegen' variety. Among the four varieties of sweet potato, 'Beletech' showed best performance resulting in $90 \%$ shoot initiation from meristem on MS medium containing $1.0 \mathrm{mg} / \mathrm{l}$ 6-benzyl amino purine (BAP), $2.0 \mathrm{mg} / \mathrm{l}$ Gibberellin (GA3) and $0.01 \mathrm{mg} / \mathrm{l}$ a-naphthalene acetic acid (NAA). In addition, the highest mean shoot number per explant $(8.0 \pm 6.2)$ was obtained from the same variety on shoot multiplication medium containing $2.0 \mathrm{mg} / \mathrm{I}$ BAP. This variety showed $100 \%$ rooting and $4.2 \pm 2.0$ mean root number on growth regulator free medium. After acclimatization, $91.4 \%$ of plants survived. All in vitro propagated plants from meristem culture and shoots cultured on medium containing $20 \mathrm{mg} / \mathrm{l}$ and $30 \mathrm{mg} / \mathrm{l}$ ribavirin were virus free.

Conclusions: This protocol can be used to produce virus free planting materials of sweet potato and distribute to the farmers to overcome the current serious sweet potato virus diseases in East Africa.

\section{Background}

Root and tuber crops are major calorie contributors and have the highest rate of dry matter production per day [1]. These crops are rich in carotenoids (carotene and anthocyanin) and dietary fiber [2]. Among the root and tuber crops, sweet potato is an important dietary source for many countries including Ethiopia.

Sweet potato ranks the seventh most important staple crop in the world and the fifth in developing countries after rice, wheat, maize and cassava [3]. It is the second important root crop after cassava in many tropical countries. The tubers are mainly used as food although the surplus is used as feed and raw materials for industries.

Because of the enormous genetic diversity of sweet potato [2], and the accompanying diversity in phenotypic and morphological traits [4], the crop has great potential for further development to accommodate specific uses. In spite of the important uses of sweet potato, production is greatly constrained by pests and diseases particularly viral diseases [5]. Viral diseases cause yield loss of up to $100 \%$ in sweet potato depending on cultivar, the type of infecting virus, stage of infection and whether the crop is infected with a single or multiple viruses [6]. 
Several viruses have been reported to infect sweet potato in Africa. The most common ones include the Sweet potato feathery mottle virus (SPFMV), Sweet potato chlorotic stunt virus (SPCSV), Sweet potato mild mottle virus (SPMMV), Sweet potato chlorotic fleck virus (SPCFV), Sweet potato latent virus (SPLV), Sweet potato caulimo-like virus (SPCaLV), Cucumber mosaic virus (CMV), Sweet potato virus $Y$, Sweet potato virus $G$ and Sweet potato leaf curl virus (SPLCV) [7-9]. Since sweet potato is cultivated from vine cuttings grown in the field from previous season, there is accumulation of viruses on the plant from generation to generation; as a consequence, total yield is significantly reduced. The most common of these viral diseases are known under the name Sweet potato virus diseases (SPVDs), caused by simultaneous infection with Sweet potato feathery mottle virus (SPFMV) and Sweet potato chlorotic stunt virus (SPCSV), [10]. SPFMV (family Potyvirideae, genus Potyvirus), is found most commonly in sweet potatoes in different parts of the world [3].

In vitro methods in sweet potato were used earlier at several international centers like International Center for Potato, (CIP), Peru, the International Institute of Tropical Agriculture (IITA), Nigeria and Asian Vegetable Research and Development Center (AVRDC), Taiwan, for conservation and virus free production of sweet potato germplasm. Besides, several national programmes in USA, Costa Rica and India have been maintaining a large number of in vitro collections of sweet potato [11, 12].

Meristem cultures and thermotherapy along with the use of antiviral drugs have been found effective in virus elimination in sweet potato. Meristem culture technique coupled with indexing by ELISA and grafting on indicator plants was used to establish healthy cultures [13]. In vitro propagation technique has been refined to develop a single medium capable of eliciting desirable response from all varieties and related species.

MS medium supplemented with sucrose and various plant growth regulators has been successfully used to establish various explant cultures of sweet potato cultivars $[14,15]$. Successful establishment of tissue and meristem culture is determined by several factors. The objective of the present study is, therefore, to produce virus free sweet potato planting materials through meristem culture and chemotherapy.

\section{Methods}

\section{Plant material}

Sweet potato vines of four varieties namely 'Beletech', 'Koka-12', 'Ogensegen' and 'TIS-8250' were obtained from Hawassa Agricultural Research Center, Hawassa, 278 km south of Addis Ababa, Ethiopia. 'Beletech' and 'Koka-12' are white fleshed whereas 'Ogensegen' and 'TIS-8250' are orange fleshed. To protect the loss of water and drying during travel, the samples were packed in plastic bags. The collected sweet potato vines were planted in pots, four vines per pot and eight pots per variety. The pots were maintained in greenhouse and watered daily at the College of Natural and Computational Sciences, Addis Ababa University, Ethiopia.

\section{Virus indexing}


Leaf portions of $1.0 \mathrm{~cm}$ diameter were taken from upper, middle and lower leaf parts of 22 greenhouse planted plants of the four varieties were used to test the presence of ten common sweet potato viruses using Nitrocellulose membranes enzyme-linked immunosorbent assay (NCM-ELISA) kits. The ten viruses were Sweet potato chlorotic stunt virus (SPCSV), Sweet potato feathery mottle virus (SPFMV), Sweet potato mild mottle virus (SPMMV), Sweet potato chlorotic fleck virus (SPCFV), Sweet potato caulimo-like virus (SPCaLV), Sweet potato mild speckling virus (SPMSV), C-6 (a flexuous rod virus), Sweet potato latent virus (SwPLV), Sweet potato virus G (SPVG), and Cucumber mosaic virus (CMV)]. Visual assessment of the development of a purple color on the sample spots of the nitrocellulose membrane was used to identify virus positive samples. After two weeks of planting in greenhouse, stock plants that were tested positive for sweet potato virus were used as source of explants for meristem culture and chemotherapy.

\section{Meristem culture}

About 1-2 cm long young shoots were excised from the two-week-old greenhouse planted virus infected stock plants. The shoot explants were washed under running tap water and rinsed in $70 \%$ ethanol for one min followed by surface sterilization with $10 \%(\mathrm{w} / \mathrm{v})$ calcium hypochlorite containing 3-4 drops of Tween20 for $15 \mathrm{~min}$ and rinsed four times with sterile double distilled water. Using forceps and scalpels, the young leaves and leaf primordia were removed under dissecting microscope. The meristems were excised using sterile syringe needle. The meristem was cultured on Petri dishes containing $25 \mathrm{ml}$ of shoot initiation medium. The shoot initiation medium was MS (Murashige and Skoog 1962) medium containing different concentrations and combinations of $\operatorname{BAP}(0.0,0.10,0.25,0.50,0.75,1.0$, and 2.50 $\mathrm{mg} / \mathrm{l}), \mathrm{GA} 3(0.0,1.0,2.0$ and $3.0 \mathrm{mg} / \mathrm{l})$ and NAA $(0.0,0.01$ and $0.05 \mathrm{mg} / \mathrm{l}), 30 \mathrm{~g} / \mathrm{l}$ sucrose and the $\mathrm{pH}$ was adjusted to 5.8 before addition of $7.0 \mathrm{~g} / \mathrm{l}$ agar. The medium was autoclaved at $121^{\circ} \mathrm{C}$ for $15 \mathrm{~min}$. Five meristems were cultured per Petri dish and six Petri dishes (30 meristems) were used per treatment. The Petri dishes were sealed with parafilm. The cultures were maintained under $12 \mathrm{~h}$ photoperiod at light intensity of $40 \mu \mathrm{mol} \mathrm{m} \mathrm{m}^{-2} \mathrm{~s}^{-1}$ at a temperature of $24 \pm 2^{\circ} \mathrm{C}$. After 2-3 weeks, the meristem cultures were transferred to the same fresh medium until shoots were emerged. The shoots were then transferred to shoot multiplication medium. Each initiated mersitem was cultured separately and labeled as an independent clone.

\section{Shoot multiplication}

Shoots initiated from mersistem were cultured on shoot multiplication medium. The shoot multiplication medium was MS medium containing 0.0, 0.5, 1.0, 1.5, 2.0, 2.5 and $3.0 \mathrm{mg} / \mathrm{l} \mathrm{BAP}$ (Table 2). Five shoot explants were cultured in each Magenta GA-7 culture vessels containing $60 \mathrm{ml}$ medium in three replications in each treatment. After four weeks, the number of shoots per explant was recorded. After the best shoot multiplication medium was obtained, stem segments with one or two nodes were also cultured on the best shoot multiplication medium.

\section{Chemotherapy}


About $1-2 \mathrm{~cm}$ long shoots were excised from the four varieties of the stock plants and sterilized in the same way as shoot sterilization for meristem culture. Sterilized shoots were cultured on MS medium containing $1.0 \mathrm{mg} / \mathrm{l}$ BAP, $3 \%$ sucrose and the $\mathrm{pH}$ was adjusted to 5.8 before adding $7.0 \mathrm{~g} / \mathrm{l}$ agar. After dissolving the agar in the medium, $40 \mathrm{ml}$ of the medium was dispensed into each baby food jars and autoclaved. From each variety, three shoots per baby food jar were cultured in three replications. The cultures were maintained in the same conditions as meristem culture. After the shoots were fully established and grown, these shoots were cultured in the same medium containing 10, 20 and $30 \mathrm{mg} / \mathrm{l}$ ribavirin and subcultured in the same fresh medium. Fifteen shoots per treatment were used. Ribavirin free medium was used as a control.

\section{Rooting and acclimatization}

About 1-2 cm long shoots from shoot multiplication medium were cultured in MS medium supplemented with 0.01 and $0.1 \mathrm{mg} / \mathrm{I}$ Indole-3-butryic acid (IBA). Growth regulators free medium was used as control. The rooted shoots were removed from the culture vessels and the roots were washed under running tap water. The plantlets were then transferred to pots containing red soil, sand and compost in the ratio of 1:2:1 respectively. The pots were covered with transparent polyethylene bags. Finally, the plantlets were transferred to greenhouse and watered every day. The polyethylene bags were removed partially after a week and completely after two weeks.

\section{Statistical analysis}

Statistical analysis of quantitative data was carried out by using SAS/JMP version 8.01 software. Differences among means were analyzed by Tukey's HSD test and a difference at probability level of $p \leq$ 0.05 was considered significant for all analyses.

\section{Results}

\section{Virus indexing}

All of the 22 stock plants of the four varieties tested for the 10 different viruses were found to be infected with Sweet Potato Feathery Mottle Virus (SPFMV). In addition, Sweet Potato Chlorotic Stunt Virus (SPCSV) was detected in 'Ogensegen' variety. Slight color change was also observed in 'Ogensegen' for Virus G. All other viruses were not detected in all varieties using NCM-ELISA test.

\section{Meristem culture}

There were significant differences among the four varieties at all concentrations of growth regulators in percentage of shoot induction from mersitem (Table 1). 'Beletech' performed best (90\%) followed by 'Ogensegen' (70\%) and then 'Koka-12' (56.7\%) on MS medium containing $1.0 \mathrm{mg} / \mathrm{l} \mathrm{BAP,} 2.0 \mathrm{mg} / \mathrm{l} \mathrm{GA3}$ and $0.01 \mathrm{mg} / \mathrm{I}$ NAA while no any shoot was initiated from 'TIS - 8250' meristems in all treatments (Table 2). Among 390 meristems of 'TIS-8250' that were cultured in all treatments, 285 (73\%) induced calli and 105 
(27\%) died. Higher concentrations of NAA (0.05 mg/l) and BAP (1.5-2.5 mg/l) induced callus. Meristems cultured on growth regulators free medium died without producing any callus or shoot.

ANOVA showed significant variation in shoot induction from meristem in all the four varieties (Table 3). Among the plant growth regulators used, NAA showed the highest effect followed by BAP and then GA3.

A little difference was observed among the four sweet potato varieties in shoot initiation. Early appearance of shoots was observed in 'Beletech' followed by 'Koka-12' and 'Ogensegen' sequentially. After six to seven weeks, well formed shoots were observed (Figs. 1A and B).

\section{Shoot multiplication}

After the emergence of the first leaves, the shoots were transferred to fresh medium containing 1.0 or 2.0 mg/l BAP (Fig. 1C). After two months of initiation, stem segments from well formed shoots, each having one or two nodes and cultured in MS medium containing $1.0 \mathrm{mg} / \mathrm{I}$ BAP, showed similar results as the shoots cultured in the same medium. The highest mean number of shoots per explant $(8.0 \pm 6.2)$ was obtained from 'Beletech' variety on MS medium containing $2.0 \mathrm{mg} / \mathrm{l}$ BAP followed by 'Koka-12' (6.7 \pm 4.2$)$ on MS medium containing $1.5 \mathrm{mg} / \mathrm{I}$ BAP (Table 4). As the concentration of BAP increased, number of shoots per explant decreased in both varieties. Lower concentrations ( 0.0 and $0.1 \mathrm{mg} / \mathrm{l})$ and higher concentration $(3.0 \mathrm{mg} / \mathrm{l})$ of BAP were not the best concentrations to multiply shoots in both varieties (Table 4). The lowest mean number of shoots per explant (1.3) from 'Beletech' and 0.7 from 'Koka-12' were obtained on growth regulators free medium.

\section{Rooting and acclimatization}

Rooting in sweet potato varieties was easy (Fig. 1D). There was even spontaneous rooting on shoot initiation, multiplication and growth regulators free media. 'Beletech' resulted in 100\% rooting on growth regulators free medium and medium containing $0.01 \mathrm{mg} / \mathrm{l}$ IBA whereas 'Koka-12' resulted in 100\% rooting on medium containing $0.1 \mathrm{mg} / \mathrm{I}$ IBA. On growth regulators free medium, $4.2 \pm 2.0$ mean number of roots per explant and abundant root hairs were obtained from 'Beletech' while 'Koka-12' produced 3.7 \pm 1.7 mean number of roots per explant on medium containing $0.1 \mathrm{mg} / \mathrm{I} \mathrm{IBA}$ (Table 5). The best mean root length $(11.25 \mathrm{~cm})$ for 'Beletech' and $11 \mathrm{~cm}$ for 'Koka-12' were obtained in growth regulators free medium.

No significant differences were observed in both rooting percentage and mean number of roots per explant between the two varieties. Different concentrations of IBA showed significant differences in both rooting percentage and mean root number explant. As concentration of IBA increased, mean root number per explant and rooting percentage decreased in 'Beletech' but the reverse was true in 'Koka-12'. When root hairs were considered, except growth regulator free medium for 'Koka-12' and 0.1 mg/l IBA containing medium for 'Beletech' which resulted in few root hairs, other concentrations showed abundant root hairs in both varieties. After acclimatization, $91.4 \%$ of 'Beletech' and 73.0\% of 'Koka-12' plants survived (Figs. 1E and F). 
All of the meristem derived nine clones of 'Beletech' and seven clones of 'Koka-12' were found to be negative for all tested viruses.

\section{Effect of ribavirin on culture performance and elimination of viruses}

Shoots cultured in MS medium supplemented with $1.0 \mathrm{mg} / \mathrm{l} \mathrm{BAP}$ and different concentrations of ribavirin showed variable responses in survival and length of shoots (Table 6). After one month culture of shoots on medium containing $30 \mathrm{mg} / \mathrm{l}$ ribavirin, $36.7 \%$ of 'Koka- 12 ' and $66.7 \%$ of 'Beletech' survived, while all shoots of 'Ogensegen' died. Survival of cultured shoots was better in the control and $10 \mathrm{mg} / \mathrm{l}$ ribavirin containing medium than shoots cultured on 20 and $30 \mathrm{mg} / \mathrm{l}$ ribavirin containing media. As the concentration of ribavirin increased, the number of survived shoots and length of shoots were significantly reduced. Because of degeneration of leaves in ribavirin treated shoots especially in 'Beletech' and 'TIS-8250', samples were taken from 'Koka-12' in all treatments and 'Ogensegen' cultured on medium containing $20 \mathrm{mg} / \mathrm{l}$ ribavirin. Among these samples, only 'Koka-12' cultured on medium containing 10 $\mathrm{mg} / \mathrm{l}$ resulted in positive result for SPFMV. All samples taken from the control showed positive result for SPFMV. 'Koka-12' performed best in 10 and 20 mg/l ribavirin followed by 'Ogensegen'.

\section{Discussion}

In this study, meristem culture and chemotherapy has been used to produce virus free planting materials of four sweet potato varieties. The essence of meristem culture is the excision of the organized apex of the shoot from a selected donor plant for subsequent in vitro culture. The culture conditions are regulated to allow only for organized outgrowth of the apex directly into a shoot, without the intervention of any adventitious organs [16].

The excised meristem is typically small (often less than $1.0 \mathrm{~mm}$ ) and is removed by sterile dissection under microscope. A major advantage of working with such a small explant is the potential that it holds for excluding pathogenic organisms that may have been present in the donor plants from the in vitro culture. The second advantage is the genetic stability inherent in the technique, since plantlet production is from an actively dividing apical meristem [17]. Shoot development directly from the meristem avoids adventitious organogenesis, ensuring that genetic instability and somaclonal variations are minimized.

Chemotherapy techniques drew much attention to get virus free varieties of sweet potato. The technique employs the application of different antiretroviral analogs in tissue cultures to retard or hinder viral replications in explants used.

Shoot initiation from meristem explants depends on many factors. The main factors that affected shoot initiation in our study were the genotype and the concentrations of growth regulators. Thirteen different growth regulators concentrations and combinations on MS medium were evaluated to get shoots from meristem. The first two combinations $(1.0 \mathrm{mg} / \mathrm{l} \mathrm{BAP,} 1.0 \mathrm{mg} / \mathrm{l} \mathrm{GA3}, 0.01 \mathrm{mg} / \mathrm{l} \mathrm{NAA}$ and $1.0 \mathrm{mg} / \mathrm{l} \mathrm{BAP,} 2.0$ $\mathrm{mg} / \mathrm{l} \mathrm{GA3}, 0.01 \mathrm{mg} / \mathrm{I} \mathrm{NAA}$ ) resulted in relatively better number of shoots for the three varieties, 'Beletech', 'Ogensegen' and 'Koka -12'. However, in both combinations, large number of callus was induced by 'TIS- 
8250 ' variety. It could be suggested that sensitivity to growth regulators is affected by the endogenous levels of hormones and it is reasonable to assume that differences in response among different sweet potato varieties resulted from the genetic differences among genotypes as it was also stated by Otani and Shimada [18]. Different reports show similar results and indicated genotypes and growth regulator concentrations highly affect meristem initiation, callus induction and shoot regeneration from callus [19, 20]. According to these authors, genotypes which form callus from meristem explants are appropriate for callus induction. In the present study, 'TIS-8250' variety induced callus in all of the treatments indicating that this variety is the most responsive variety for callus induction among all the four varieties. On the other hand, these authors reported that the responses of meristem initiation to plant growth regulators have varied with the type, concentration and combination of growth regulators, age and type of explants and genotypes.

Results obtained in the present study showed that sensitivity to exogenous growth regulators is probably affected by the endogenous hormonal level, which controls many circumstances expressed by the genetic makeup of the cells. The type of auxin used in initiation medium was found significant for meristem initiation and specific to the individual cultivars [21]. In the light of the results obtained in this study, each of the growth regulators used had different effects on shoot initiation from meristems of sweet potato varieties. As it was reported by Gong et al. [22], shoot initiation from meristem requires specific concentration and combination of growth regulators. Kakuei and Salehi [23] reported that with increasing concentration of growth regulators, most of the shoots of Dracaena sanderiana showed deformity.

Interaction effects among 'Beletech', 'Koka-12' and 'Ogensegen' varieties and growth regulators (BAP, NAA and GA3) were significant at $5 \%$ probability level for meristem initiation. MS medium containing NAA, BAP and GA3 are critical for shoot initiation from meristem of sweet potato varieties [21]. On the other hand, Oggema et al. [24] pointed out that lower concentrations of NAA and BAP in initiation medium resulted in higher shoot initiation percentage from meristem. When NAA concentration was increased from 0.01 to $0.05 \mathrm{mg} / \mathrm{l}$, the number of shoot production sharply decreased from 27 shoots to 5 shoots in 'Beletech', 21 shoots to 0.0 in 'Koka-12' and 17 shoots to 0.0 in 'Ogensegen' and enhanced callus formation. Similarly, Rafi and Salehi [25] reported increasing the concentration of NAA to $3.0 \mu \mathrm{M}$ reduced the number and length of proliferated shoots of Himalayan cedar. Compact callus formation with increase in concentration of NAA was reported by Robbins [26]. Increased concentrations of BAP resulted in more callus than shoots in all of the varieties. Similar trend was also observed with increase in the concentration of GA3.

The results of the present study showed that $1.0 \mathrm{mg} / \mathrm{l} \mathrm{BAP,} 2.0 \mathrm{mg} / \mathrm{l} \mathrm{GA3}$ and $0.01 \mathrm{mg} / \mathrm{l} \mathrm{NAA}$ were found to be optimum in shoot initiation from meristem in 'Beletech', 'Ogensegen' and 'Koka-12'. This combination was repeated once and similar results were recorded. In all of the growth regulators combinations, shoot initiation was not possible for 'TIS-8250' but callus formation was highly evident. 
Shoots initiated from meristem culture were cultured on different concentrations of BAP. Shoot multiplication response per explant was increased tremendously when $2.0 \mathrm{mg} / \mathrm{l}$ and $1.5 \mathrm{mg} / \mathrm{l} \mathrm{BAP}$ was used for 'Beletech' and 'Koka-12' respectively. However, further increase in concentration of BAP resulted in sharp decrease in shoot multiplication response for both varieties. This is possibly due to the reason that normal development of somatic tissue requires a fine temporal and spatial regulation of cell division, enlargement and differentiation that could be achieved by optimum concentration of cytokinins as also reported by Ammirato [27]. Similarly, Shahcheraghi and Shekafandeh [28] reported increasing kinetin from 6 to $8 \mathrm{mg} / \mathrm{l}$ significantly reduced the number of shoots in Ficus carica indicating supra-optimal concentration of cytokinin reduces rate of shoot multiplication.

The results indicated that IBA is important factor for root length, root number and abundance of root hair formation. However, there was no significant difference in percentage of rooting between medium containing IBA and growth regulators free medium that was used as a control. Since sweet potato is vegetatively propagated plant, it roots easily. Wondimu et al. [9] transferred microshoots directly to greenhouse for acclimatization by bypassing the in vitro rooting stage and obtained $100 \%$ rooting. Significant differences $(P<0.05)$ were shown between the two sweet potato varieties in number of roots and root length. The highest mean number of roots was exhibited by variety 'Beletech' in growth regulator free medium, which was used as a control. This was different from results obtained by Lity and Conooer [29] who reported that IBA significantly increased the number of roots produced in sweet potato varieties. On the other hand, the highest mean number of roots in 'Koka-12' was obtained on medium containing $0.1 \mathrm{mg} / \mathrm{I} \mathrm{IBA}$. These differences may be due to differences in genotype, which may have different concentrations of endogenous auxin. The number of roots per shoot increased when IBA was used in low concentration for 'Beletech' and relatively high concentration for 'Koka -12'. Growth regulator free medium resulted in longest root with root hairs in both genotypes. Similarly, Sepehrtaj and Shahsavar [30] reported increasing the concentration of IBA resulted in decrease in the number of roots in citrus. Spontaneous rooting was also common in initiation medium as also reported by Oggema et al. [24] probably due to high endogenous concentration of auxin.

Plantlets are ready to be established in the soil when they have two or three leaves and at least one strong root. Soil: sand: compost mixture in a ratio of 1:2:1 resulted in $91.4 \%$ survival of plants after acclimatization. Kuo et al. [31] reported soil mixtures with high peat content often lead to slower growth and a higher death rate.

Since sweet potato is vegetatively propagated by the use of vine cuttings and storage roots, almost all germplasms are known to be infected with viruses [32]. Viral infections can have a dramatic effect on yield and marketable quality of a crop and also can adversely affect international distribution of sweet potato germplasm [6]. Some viruses like sweet potato feathery mottle virus can alone decrease the yield by $40 \%$ and in combination with other viruses, the loss reaches $90 \%$ [33]. SPFMV is the most common sweet potato virus which occurs world-wide. This was also confirmed in our study that all of the stock plants tested positive for SPFMV. The best control method for potato viruses is production of healthy plants from meristem culture. To produce healthy plants, small meristems $(0.11-0.25 \mathrm{~mm}$ diameter) are 
more responsive than big meristems. In the present study, the two main virus elimination methods, meristem culture and chemotherapy, were used for virus elimination. Serological method, NCM-ELISA, was used to test for the presence of viruses in the stock plants and meristem derived and chemical treated plantlets. Meristem culture was found to be very effective in eliminating viruses. Its virus elimination efficiency reached $100 \%$ in our study and $75-80 \%$ elimination efficiency was reported by Kuo et al. [31]. In another study, Mellor and Stace-Smith [34] cultured apical meristems of four potato cultivars in modified MS solid medium with BAP, NAA and GA3 and they obtained $68.1-86.6 \%$ virus free plantlets. In the stock plants tested, 'Ogensegen' showed very deep purple color showing that it is severely attacked by viruses. Symptoms in the leaves of this plant are also indicative of infection by viruses. NCM-ELISA confirmed the synergistic effect of the three viruses (SPFMV, SPCSV and SPVG) in this variety. 'Beletech' and 'Koka-12' showed light purple color showing that they are infected only by single virus, SPFMV.

Antiviral chemicals can be used as additives in the culture medium [35], and one of the most widely used is ribavirin (1- $\beta$-ribofuranosyl-1, 2, 4-triazole-3-carboxamide) also known as virazole. This compound is a guanosine analog with broad-spectrum activity against animal viruses and appears also to be active against plant virus replication in whole plants [22]. Increasing concentrations of ribavirin and increasing length of culture incubation in the presence of the compound typically increases the effectiveness of virus elimination [34], but slow growth and phytotoxicity may be evident at high concentrations. The efficiency of ribavirin in the elimination of plant viruses is subject to its concentrations, type of host plant genetic material, and type of virus. Studies indicate applications of antivirus agents inhibit synthesis of virus RNA [36]. Mangal et al. [37] reported that by in vitro chemotherapy, with application of $20 \mathrm{mg} / \mathrm{l}$ ribavirin, $55.5 \%$ virus-free sweet potato plants were obtained but in our study, 'Koka-12' and 'Ogensegen' varieties, $100 \%$ of the shoots treated with $20 \mathrm{mg} / \mathrm{l}$ ribavirin were free from viruses. Nevertheless, lower concentration $(10 \mathrm{mg} / \mathrm{l})$ failed to produce similar results in all treated shoots. Al-Mazrooei et al. [21] reported that $30 \mathrm{mg} / \mathrm{l}$ ribavirin treated shoots were $100 \%$ free from viruses with sever phytotoxicity effect. In our study, shoots cultured on medium containing ribavirin at concentrations ranging from 10-30 mg/1 had both virus elimination and phytotoxicity effects. In $30 \mathrm{mg} / \mathrm{l}$ ribavirin treated samples, significant number of shoots of 'Koka-12' followed by 'Beletech' and all shoots of 'Ogensegen' died. All shoots of 'TIS-8250' cultured in all concentrations of ribavirin turned to calli. All shoots cultured on the control (ribavirin free medium) tested positive for viruses present in the mother plants.

The development of pale green pigmentation in the early storage of meristems could be an indication of survival of meristem. If the meristem cultures become white and translucent, it could be an indication of degeneration. When the first initiated shoots were transferred to the same fresh medium or 1.0 or 2.0 $\mathrm{mg} / \mathrm{l}$ BAP, all of them died. This happened frequently during the subsequent cultures. Several authors drew the attention to the effect of initiation medium on stimulation of plantlet survival for sweet potato as Al-Mazrooei et al. [21] pointed out that the carry over effect of the initiation medium on subsequent growth of plantlets especially in recalcitrant varieties. According to these authors, the effect of auxin on initiation medium is critical and specific to the individual cultivars. One of the most important approaches for overcoming in vitro recalcitrance problems is the optimization of plant growth regulators. However, cultures are under the control of both endogenous and exogenous plant growth regulators. Therefore, 
achieving the optimum exogenous balance of the key growth regulators can be critical and their appropriate application can effectively overcome certain recalcitrance problems [38]. Finally, callusing in the initiation medium was frequently observed in all varieties especially in 'TIS-8250' in which no shoot initiation was possible in all of the treatments used.

In this study, initiation of shoots was successful on auxin, cytokinin and gibberellins containing medium. Growth regulator free initiation medium showed significant difference than plant growth regulator containing medium. BAP containing medium showed the highest number of shoots per explant. Shoots cultured on growth regulators free medium and IBA containing medium rooted well. Rooted plantlets were then transferred into pots and successfully acclimatized in the greenhouse.

\section{Conclusions}

Among ten different viruses tested, SPFMV were detected in all the four varieties but additional virus (SPCSV) and possibly SPVG was detected in 'Ogensegen'. Elimination of these viruses using meristem culture and chemotherapy was successful. The results of the present study might significantly contribute to the virus free production and consequent increase in sweet potato yield and quality. The enormous yield loss and low quality problems can be overcome by distributing these virus free planting materials to farmers.

\section{Abbreviations}

AVRDC: Asian Vegetable Research and Development Center;

BAP: 6-Benzaylaminopurine;

CIP: International Center for Potato;

CMV: Cucumber mosaic virus,

GA3: Gibberellin;

IBA: Indole-3-butyric acid.

IITA: International Institute of Tropical Agriculture;

MS: Murashige and Skoog 1962;

NAA: a-naphthalene acetic acid;

NCM-ELISA: Nitrocellulose Membranes Enzyme-Linked Immunosorbent Assay;

SPCaLV: Sweet potato caulimo-like virus, 
SPCFV: Sweet potato chlorotic fleck virus,

SPCSV: Sweet potato chlorotic Stunt virus;

SPFMV: Sweet potato feathery mottle virus;

SPLCV: Sweet potato leaf curl virus;

SPLV: Sweet potato latent virus;

SPMMV: Sweet potato mild mottle virus;

SPMSV: Sweet potato mild speckling virus,

SPVDs: Sweet potato virus diseases;

SPVG: Sweet potato virus G.

\section{Declarations}

\section{Ethics approval and consent to participate}

Not applicable.

\section{Consent for publication}

Not applicable.

\section{Availability of data and materials}

All data generated or analysed during this study are included in this article.

\section{Competing interests}

The authors declare that they have no competing interests.

\section{Funding}

This project is funded by the Swedish International Development Agency and Addis Ababa University.

\section{Authors' contributions}

TF initiated, designed and supervised the project, performed part of the experiments and wrote the manuscript. NJ did the experiments and analyzed the data. 
The authors acknowledge the Swedish International Development Agency and Addis Ababa University for financial support and Dr. Adane Abraham for providing laboratory facility for virus indexing.

\section{References}

1. Chandrasekara A, Kumar TJ. Roots and Tuber Crops as Functional Foods: A Review on Phytochemical Constituents and Their Potential Health Benefits. Int J Food Sci. 2016; https://doi.org/10.1155/2016/3631647.

2. Zhang D, Chislain M, Huaman Z, Golmirzaie A, Hijmans RJ. RAPD variation in sweet potato (Ipomoea batatas (L.) Lam.) cultivars from South America and Papua New Guinea. Genet Resour Crop Evol. 1998; 45:271-277.

3. Loebenstein G, Fuentes S, Cohen J, Salazar LF. Sweet potato. In: Loebenstein G, Thottappilly G. editors. Virus and Virus-Like Diseases of Major Crops in Developing Countries. Dordrecht: Kluwer Academic Publishers; 2003. p. 223-248.

4. Woolfe JA. Sweet potato: an Untapped Food Resource. Cambridge: Cambridge University Press and the International Potato Center (CIP); 1992.

5. Karyeija RF, Gibson RW, Valkonen JPT. The significance of sweet potato feathery mottle virus in subsistence sweet potato production in Africa. Plant Dis. 1998; 82:4-15.

6. Ngeve JM, Bouwkamp JC. Effect of sweet potato virus disease on the yield of sweet potato genotypes in Cameroon. Exp Agr. 1991; 27:221-225.

7. Mukasa SB, Rubaihayo PR, Valkonen JPT. Incidence of viruses and viruslike diseases of sweetpotato in Uganda. Plant Dis. 2003; 87(4):329-335.

8. Dugassa G, Feyissa T. In vitro production of virus-free sweet potato [/pomoea batatas (L.) Lam] by meristem culture and thermotherapy. SINET Ethiop J Sci. 2011; 34 (1):17-28.

9. Wondimu T, Feyissa T, Badada G. Meristem culture of selected sweet potato (Ipomoea batatas Lam.) cultivars to produce virus-free planting material. J Hort Sci Biotechnol. 2011; 87(3): 255-260.

10. Gibson RW, Kaitisha GC, Randrianaivoarivony JM, Vetten HJ. Identification of the East African strain of sweet potato chlorotic stunt virus as a major component of sweet potato virus disease in southern Africa. Plant Dis. 1998; 82(9):1063.

11. Karyeija RF, Kreuze JF, Gibson RW, Valkonen JPT. Synergistic interactions of a potyvirus and a phloem-limited crinivirus in sweet potato plants. Virology. 2000; 269:26-36.

12. Latham JR, Wilson AK. Transcomplementation and synergism in plants: implications for viral Transgenes. Mol Plant Pathol. 2008; 9:85-103.

13. Mandal BB, Chandel KPS, Dwivedi S. Cryopreservation of yam (Dioscorea) shoot apices by encapsulation-dehydration. Cryo Lett. 1996; 17:165-174.

14. Schaefers GA, Terry ER. Insect transmission of sweet potato disease agents in Nigeria. 1976; 66:642645. 
15. Mukasa SB, Rubaihayo PR, Valkonen JPT. Interactions between a crinivirus, an impomovirus and a potyvirus in coinfection sweet potato plants. Plant Pathol. 2006; 55: 458-467.

16. Debergh PC, Read PE. Micropropagation. In: Debergh P, Zimmerman RH. Editors. Micropropagation: Technology and Application. Dordrecht, New York, NY Norwell, MA London: Kluwer Academic Publishers; 1991. p. 1-13.

17. Ancora G, Belli-Donini ML, Cozzo L. Globe artichoke plants obtained from shoot apices through rapid in vitro micropropagation. Hort Sci. 1981; 14:207-213.

18. Otani M, Shimada T. Efficient embryogenic callus formation in sweet potato (Ipomoea batatas (L.) Lam.). Jpn J Breed. 1996; 46:257-260.

19. Dhir SK, Oglesby J, Bhagsari AS. Plant regeneration via somatic embryogenesis, and transient gene expression in sweet potato protoplasts. Plant Cell Rep. 1998; 17:665-669.

20. Esmaeili S, Salehi H, Khosh-Khui M. Direct and indirect in vitro plant regeneration of two commercial cultivars of perennial ryegrass. Adv Hort Sci. 2018; 32(2):273-280.

21. Al-Mazrooei S, Bhatti MH, Henshaw GG, Taylor NJ, Blakesley D. Optimization of somatic embryogenesis in fourteen cultivars of sweet potato (Ipomoea batatas Lam.). Plant Cell Rep. 1997; 16:710-714.

22. Gong $Y$, Gao F, Tang K. In vitro high frequency direct root and shoot regeneration in sweet potato using the ethylene inhibitor silver nitrate. S Afr J Bot. 2005; 71(1):110-113.

23. Kakuei F, Salehi H. Factors affecting in vitro propagation of Dracaena sanderiana Sander ex Mast. cultivars. I. Sterilization, explant browning, and shoot proliferation. Adv Hort Sci. 2015; 29(4):159164.

24. Oggema JN, Ouma JP, Kinyua MG. Response of five locally adapted sweet potato (Ipomoea batatas (L.) Lam.) cultivars to in vitro plant regeneration via direct and indirect embryogenesis. Asian J Plant Sci. 2007; 6(4):617-622.

25. Rafi ZN, Salehi H. Factors affecting in vitro propagation of some genotypes of Himalayan cedar [Cedrus deodara (Roxb. ex Lamb) G. Don.]. Adv Hort Sci. 2018; 32(4): 479-485.

26. Robbins WJ. Cultivation of excised root tips and stem tips under sterile conditions. Bot Gaz. 1922; 73(5):376-390.

27. Ammirato PV. Organizational events during embryogenesis. - In: Green CE, Somer DA, Hackett WP, Bisboer DD. Editors. Plant tissue and cell culture, Plant Biology. New York: Alan R. Liss. Inc; 1987. p. 57-81. p. 57-81.

28. Shahcheraghi ST, Shekafandeh A. Micropropagation of three endemic and endangered fig (Ficus carica) genotypes. Adv Hort Sci. 2016; 30(3):129-134.

29. Lity RE, Conooer RA. In vitro propagation of sweet potato. Hort Sci. 1978; 13(6):659-660.

30. Sepehrtaj A, Shahsavar AR. Uniform and virus-free citrus rootstocks production via nucellus culture. Adv Hort Sci. 2017; 31(3):175-181. 
31. Kuo CG, Shen BJ, Green SK, Lee DR. Virus-free sweet potato storage roots derived from meristem-tips and leaf cutting. Sci 1985; 26(3):231-240.

32. Green SK. Uneven distribution of two potyviruses (feathery mottle virus and latent virus) in sweet potato plants and its implications on virus indexing of meristem derived plants. Trop Pest Manag. 1987; 34(3):298-302.

33. Njeru RW, Mburu MWK, Cheramgon E, Gibson RW, Obudho E, Yobera D. Studies on the physiological effects of viruses on sweet potato yield in Kenya. Ann Appl Biol. 2004; 145:71-76.

34. Mellor FC, Stace-Smith R. Virus-free potatoes through meristem culture. In: Bajaj YPS, editors. Biotechnology in Agriculture and Forestry. Vol Berlin, Heidelberg: Springer; 1987. P. 30-39.

35. Quak F. Meristem culture and virus-free plants. In: Reinert J, Bajaj YPS, editors. Applied and fundamental aspects of plant cell, tissue, and organ culture. Berlin, Heidelberg: Springer-Verlag; 1977. P. 598-615.

36. Wang MR, Cui ZH, Li JW, Hao XY, Zhao L, Wang QC. In vitro thermotherapy-based methods for plant virus eradication. Plant Methods. 2018; 14:87. https://doi.org/10.1186/s13007-018-0355-y.

37. Mangal M, Bhardwaj VS, Handa A. Production of virus-free carnation plants through heat therapy. Def Sci J. 2004; 54(1):53-56.

38. Erica EB. Special symposium: in vitro plant recalcitrance. An introduction. In Vitro Cell Dev Biol Plant. 2000; 36:141-148.

\section{Tables}

Table 1 Percentage of shoot initiation from meristem cultures of three sweet potato varieties on MS medium containing BAP, GA3 and NAA 


\begin{tabular}{cccccc}
\hline \multicolumn{1}{c}{ Growth regulators (mg/l) } & \multicolumn{3}{c}{ Shoot initiation (\%) } \\
\hline BAP & GA3 & NAA & 'Beletech' & 'Koka-12' & 'Ogensegen' \\
\hline 1.00 & 1.00 & 0.01 & $80.0^{\mathrm{ab}}$ & $46.7^{\mathrm{ab}}$ & $50.0^{\mathrm{ab}}$ \\
1.00 & 2.00 & 0.01 & $90.0^{\mathrm{a}}$ & $70.0^{\mathrm{a}}$ & $56.7^{\mathrm{a}}$ \\
1.00 & 2.00 & 0.05 & $16.7^{\mathrm{bc}}$ & $0.0^{\mathrm{c}}$ & $0.0^{\mathrm{c}}$ \\
2.50 & 1.00 & 0.01 & $3.3^{\mathrm{c}}$ & $3.3^{\mathrm{c}}$ & $0.0^{\mathrm{c}}$ \\
2.50 & 2.00 & 0.01 & $3.3^{\mathrm{c}}$ & $0.0^{\mathrm{c}}$ & $0.0^{\mathrm{c}}$ \\
2.50 & 1.00 & 0.05 & $3.3^{\mathrm{c}}$ & $0.0^{\mathrm{c}}$ & $0.0^{\mathrm{c}}$ \\
1.00 & 3.00 & 0.01 & $0.0^{\mathrm{c}}$ & $6.7^{\mathrm{bc}}$ & $0.0^{\mathrm{c}}$ \\
1.50 & 1.00 & 0.05 & $6.7^{\mathrm{c}}$ & $6.7^{\mathrm{bc}}$ & $0.0^{\mathrm{c}}$ \\
0.75 & 1.00 & 0.01 & $33.3^{\mathrm{abc}}$ & $0.0^{\mathrm{c}}$ & $26.7^{\mathrm{abc}}$ \\
0.10 & 1.00 & 0.01 & $10.0^{\mathrm{bc}}$ & $10.0^{\mathrm{bc}}$ & $20.0^{\mathrm{bc}}$ \\
0.25 & 1.00 & 0.01 & $20.0^{\mathrm{bc}}$ & $10.0^{\mathrm{bc}}$ & $33.3^{\mathrm{abc}}$ \\
0.50 & 1.00 & 0.01 & $26.7^{\mathrm{abc}}$ & $3.3^{\mathrm{c}}$ & $0.0^{\mathrm{c}}$ \\
0.00 & 0.00 & 0.00 & $0.0^{\mathrm{c}}$ & $0.0^{\mathrm{c}}$ & $0.0^{\mathrm{c}}$ \\
\hline
\end{tabular}

Means within each column connected by the same superscript (a-c) are not significantly different at $5 \%$ probability level

Table 2 Effect of genotype on shoot initiation from meristem

\begin{tabular}{ll}
\hline Varieties & Mean number of shoots per explant \\
\hline 'Beletech' & $6.770^{\mathrm{a}}$ \\
'Ogensegen' & $4.307^{\mathrm{ab}}$ \\
'Koka-12' & $3.610^{\mathrm{ab}}$ \\
'TIS-8250' & $0.000^{\mathrm{c}}$ \\
\hline
\end{tabular}


Means connected by the same superscript (a-c) are not significantly different at 5\%

probability level

Table 3 ANOVA for comparison of the treatment and variety effects on shoot initiation from meristem

\begin{tabular}{llll}
\hline ANOVA/ Dependent variables & \multicolumn{2}{l}{ Initiation (\%) } \\
\hline Source of variation & $\boldsymbol{d} \boldsymbol{f}$ & Mean square & $\boldsymbol{F}$ \\
\hline VAR & 3 & 1146.55 & $2.5568^{*}$ \\
BAP & 1 & 812.188 & $1.6814^{*}$ \\
GA3 & 1 & 96.495 & 0.194 \\
NAA & 1 & 1077.48 & $2.2554^{*}$ \\
VAR X BAP & 7 & 656.948 & 1.4193 \\
VAR x GA3 & 7 & 512.178 & 1.0541 \\
VAR x NAA & 7 & 696.769 & $1.5262^{*}$ \\
BAP x GA3 & 3 & 660.59 & 1.3797 \\
BAP x NAA & 3 & 512.997 & 1.0511 \\
GA3 x NAA & 3 & 461.098 & 0.9386 \\
VAR x BAP x GA3 & 15 & 417.901 & 0.8047 \\
VAR x BAP x NAA & 15 & 377.049 & 0.703 \\
BAP x NAA xGA3 & 7 & 547.601 & 1.1402 \\
VAR x BAP x GA3 x NAA & 31 & 289.489 & 0.3621 \\
Error & 566 & 72.372 & \\
Total & 714 & & \\
\hline
\end{tabular}

*5\% significance level ( $F$ test)

Table 4 Number of shoots per explant on MS medium containing different concentrations of BAP. Data given as means $\pm \mathrm{SD}$ 


\begin{tabular}{lll}
\hline \multirow{2}{*}{ BAP (mg/l) } & \multicolumn{2}{c}{ Number of shoots per explant } \\
\cline { 2 - 3 } & 'Beletech' & 'Koka-12' \\
\hline 0.0 & $1.3 \pm 1.2^{\mathrm{c}}$ & $1.1 \pm 0.4^{\mathrm{c}}$ \\
0.1 & $1.7 \pm 1.1^{\mathrm{c}}$ & $1.3 \pm 0.5^{\mathrm{c}}$ \\
0.5 & $2.7 \pm 2.0^{\mathrm{abc}}$ & $4.3 \pm 2.5^{\mathrm{ab}}$ \\
1.0 & $6.3 \pm 4.5^{\mathrm{ab}}$ & $5.0 \pm 3.6^{\mathrm{ab}}$ \\
1.5 & $6.5 \pm 4.5^{\mathrm{a}}$ & $6.7 \pm 4.2^{\mathrm{a}}$ \\
2.0 & $8.0 \pm 6.2^{\mathrm{a}}$ & $6.0 \pm 3.6^{\mathrm{a}}$ \\
2.5 & $2.0 \pm 1.7^{\mathrm{bc}}$ & $2.0 \pm 1.7^{\mathrm{bc}}$ \\
3.0 & $1.7 \pm 1.3^{\mathrm{c}}$ & $1.7 \pm 1.1^{\mathrm{c}}$ \\
\hline
\end{tabular}

Means within each column connected by the same superscript (a-c) are not significantly different at $5 \%$ probability level

Table 5 Percentage of rooting and mean number of roots per explant of 'Beletech' and 'Koka-12' on MS medium containing different concentrations of IBA. Mean values are shown as $\pm \mathrm{SD}$

\begin{tabular}{lcccccc}
\hline IBA (mg/l) & \multicolumn{2}{c}{ No. of roots per explant } & \multicolumn{2}{c}{ Root length (cm) } & \multicolumn{2}{c}{ Rooting percentage } \\
\hline \multirow{2}{*}{0.00} & 'Beletech' $^{2}{ }^{2}$ Koka-12' & 'Beletech' & 'Koka-12' & 'Beletech' & 'Koka-12' \\
\cline { 2 - 7 } 0.01 & $4.2 \pm 2.0^{\mathrm{a}}$ & $2.3 \pm 1.5^{\mathrm{ab}}$ & $11.25^{\mathrm{a}}$ & $11.00^{\mathrm{a}}$ & $100^{\mathrm{a}}$ & $80.0^{\mathrm{ab}}$ \\
0.10 & $3.1 \pm 1.6^{\mathrm{ab}}$ & $2.8 \pm 1.2^{\mathrm{ab}}$ & $6.25^{\mathrm{c}}$ & $2.75^{\mathrm{bc}}$ & $100^{\mathrm{a}}$ & $93.3^{\mathrm{a}}$ \\
& $1.9 \pm 0.9^{\mathrm{ab}}$ & $3.7 \pm 1.7^{\mathrm{a}}$ & $8.20^{\mathrm{ab}}$ & $2.00^{\mathrm{c}}$ & $93.3^{\mathrm{a}}$ & $100^{\mathrm{a}}$ \\
\hline
\end{tabular}

Means within each column connected by the same superscript (a-c) are not significantly different at 5\% probability level

Table 6 Effect of ribavirin on shoot cultures of sweet potato varieties. Shoot lengths are shown as mean values

\begin{tabular}{|c|c|c|c|c|c|c|c|c|}
\hline Ribavirin (mg/l) & \multicolumn{2}{|c|}{ 'Koka-12' } & \multicolumn{2}{|c|}{ 'Ogensegen' } & \multicolumn{2}{|c|}{ 'Beletech' } & \multicolumn{2}{|l|}{ 'TIS-8250' } \\
\hline & SS \% & $\mathrm{SL}(\mathrm{cm})$ & SS \% & $\mathrm{SL}(\mathrm{cm})$ & SS \% & $\mathrm{SL}(\mathrm{cm})$ & SS \% & SL \\
\hline 0 & $100^{\mathrm{a}}$ & $5.6^{\mathrm{a}}$ & $76.7^{a}$ & $3.00^{\mathrm{a}}$ & $96.7^{a}$ & $4.0^{\mathrm{a}}$ & All callus & \\
\hline 10 & $90.0^{\mathrm{a}}$ & $5.2^{\mathrm{ab}}$ & $40.0^{\mathrm{bc}}$ & $2.75^{\mathrm{a}}$ & $76.7^{\mathrm{ab}}$ & $2.0^{\mathrm{ab}}$ & All callus & - \\
\hline 20 & $80.0^{\mathrm{ab}}$ & $5.2^{\mathrm{ab}}$ & $26.7^{\mathrm{c}}$ & $1.60^{\mathrm{ab}}$ & $66.7^{\mathrm{ab}}$ & $1.5^{\mathrm{c}}$ & All callus & - \\
\hline 30 & $36.7^{\mathrm{c}}$ & $3.7^{\mathrm{C}}$ & $0.0^{\mathrm{C}}$ & $0.00^{\mathrm{c}}$ & $66.7^{\mathrm{ab}}$ & $1.5^{\mathrm{c}}$ & All callus & - \\
\hline
\end{tabular}


Means within each column connected by the same superscript (a-c) are not significantly different at 5\%probability level.

SS- Survived shoots; SL- Shoot length

\section{Figures}
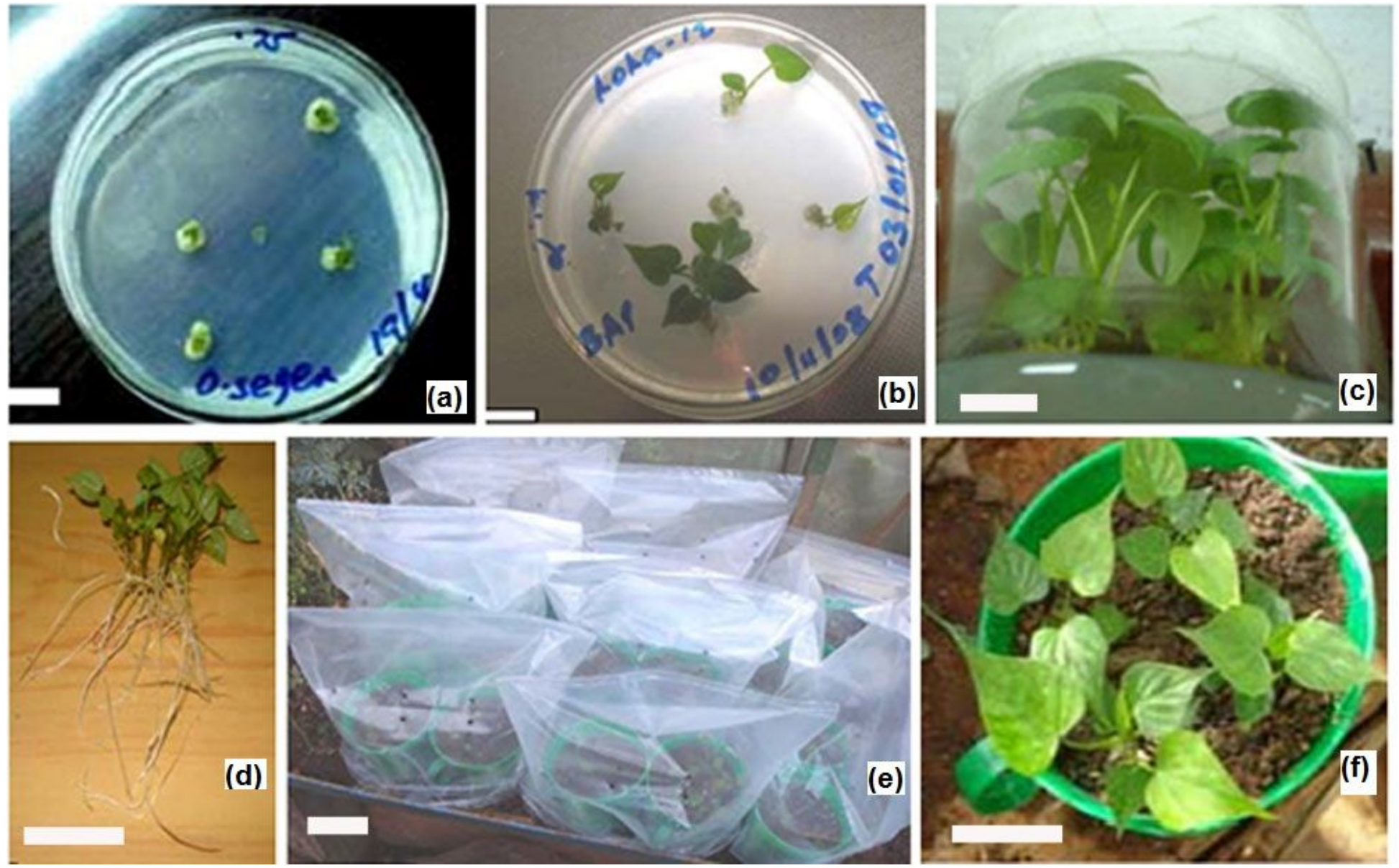

\section{Figure 1}

Production of sweet potato plants from mersitem. A) Culture initiation, B) Shoot production from meristem, C) Shoot multiplication, D) Rooting, E) Acclimatization in polyethylene bags, F) Acclimatized plants. Bars: $a, b, c$ and $d=1.0 \mathrm{~cm} ; e$ and $f=10 \mathrm{~cm}$. 